\title{
A case of primitive trigeminal artery infarction
}

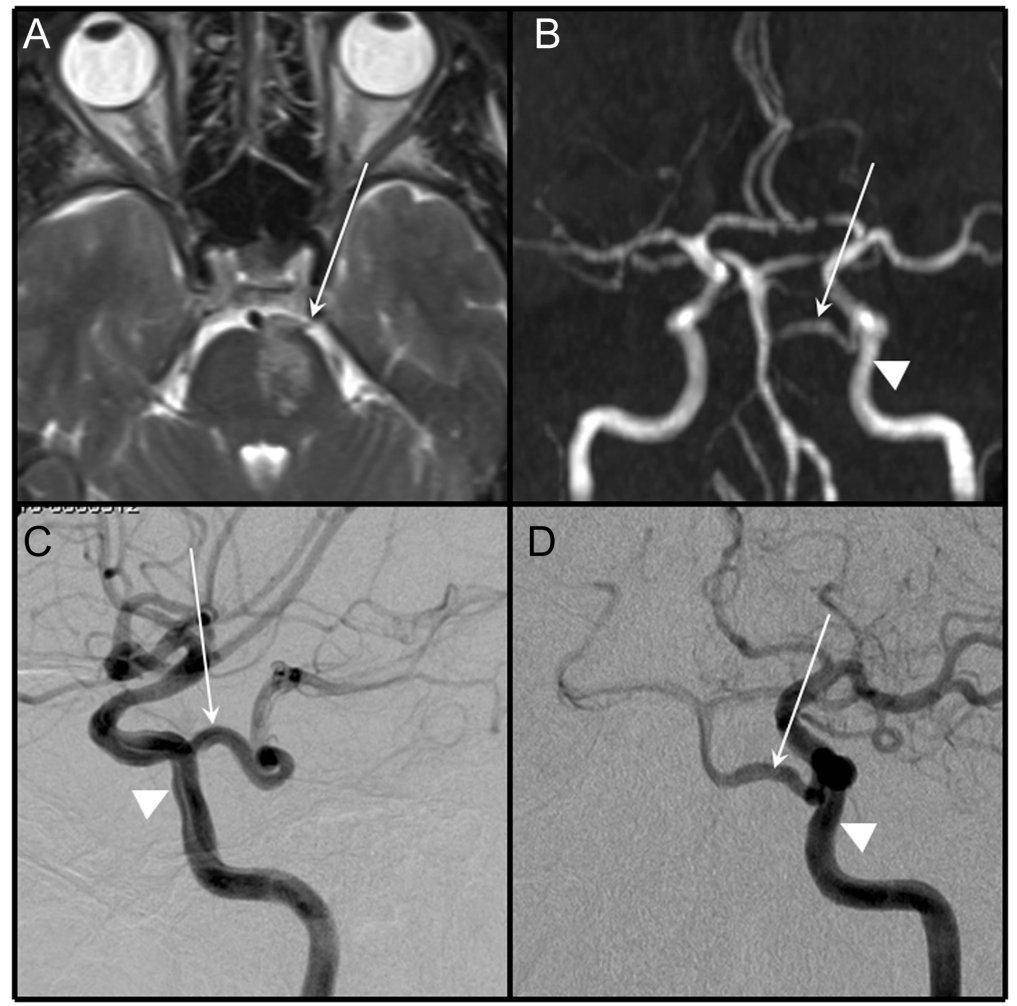

White arrow points to the primitive trigeminal artery (A-D). MRI, fluid-attenuated inversion recovery sequence, demonstrating the left ventral pontine infarction (A). Magnetic resonance angiography demonstrates proximal hypoplastic-stenotic vertebrobasilar system (B). Selective left internal carotid artery angiogram: lateral (C) and anteroposterior view (D) (same viewing angle as in B). Triangular arrowhead points to the left internal carotid artery (B-D).

$\mathrm{W}$

ithin minutes following an altercation with police, a 55-year-old man noted onset of speech difficulty and right-sided weakness without headache or neck pain. Dysarthria and right hemiparesis (grade 4/5) without ocular disturbance was found. Left ventral hemipontine infarction was documented from the ipsilateral tortuous primitive trigeminal artery (figure). Cerebral angiogram failed to reveal underlying arterial dissection.

Persistent anastomosis from a cavernous portion of internal cerebral artery to rostral basilar artery is unusual, with an estimated incidence of $0.2 \% .{ }^{1}$ Although the artery has been implicated as a conduit of a carotid artery to posterior cerebral artery distribution embolic stroke, ${ }^{2}$ our case illustrates that localized occlusive process may also occur.

Suichi Suzuki, MD, PhD, Gregory Youngnam Chang, MD, FAAN

From the Department of Radiology (S.S.), University of California at Irvine Medical Center, Irvine; and Department of Neurology (G.Y.C.), Barrow Neurological Institute, Phoenix, AZ.

Disclosure: The authors report no disclosures.

Address correspondence and reprint requests to Dr. Gregory Y. Chang, Barrow Neurological Institute, 500 W. Thomas Road, Suite 300, Phoenix, AZ 85013; gychang@yahoo.com

Received June 17, 2010. Accepted in final form August 30, 2010.

1. Luh GY, Dean BL, Tomsick TA, Wallace RC. The persistent fetal carotid-vertebrobasilar anastomoses. AJR Am J Roentgenol 1999;172:1427-1432.

2. Gasecki AP, Fox AJ, Lebrun LH, et al. Bilateral occipital infarctions associated with carotid stenosis in a patient with persistent trigeminal artery: The Collaborators of the North American Carotid Endarterectomy Trial (NASCET). Stroke 1994;25:1520-1523. 


\title{
Neurology
}

\author{
A case of primitive trigeminal artery infarction \\ Suichi Suzuki and Gregory Youngnam Chang \\ Neurology 2010;75;S66 \\ DOI 10.1212/WNL.0b013e3181fb3604
}

\section{This information is current as of November 1,2010}

\section{Updated Information \&} Services

References

Subspecialty Collections

Permissions \& Licensing

Reprints including high resolution figures, can be found at: http://n.neurology.org/content/75/18_Supplement_1/S66.full

This article cites 2 articles, 1 of which you can access for free at: http://n.neurology.org/content/75/18_Supplement_1/S66.full\#ref-list-1

This article, along with others on similar topics, appears in the following collection(s):

\section{All Cerebrovascular disease/Stroke}

http://n.neurology.org/cgi/collection/all_cerebrovascular_disease_strok e

\section{Infarction}

http://n.neurology.org/cgi/collection/infarction

MRI

http://n.neurology.org/cgi/collection/mri

Information about reproducing this article in parts (figures,tables) or in its entirety can be found online at:

http://www.neurology.org/about/about_the_journal\#permissions

Information about ordering reprints can be found online:

http://n.neurology.org/subscribers/advertise

Neurology ${ }^{\circledR}$ is the official journal of the American Academy of Neurology. Published continuously since 1951, it is now a weekly with 48 issues per year. Copyright Copyright (? 2010 by AAN Enterprises, Inc.. All rights reserved. Print ISSN: 0028-3878. Online ISSN: 1526-632X.

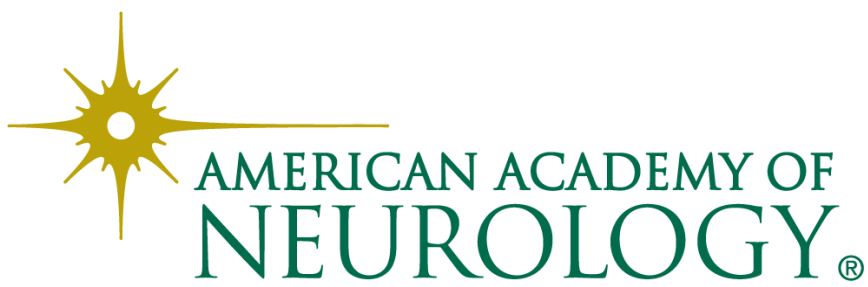

